\title{
Komparasi Yield Nata De Tomato Dengan Nata De Coco Berdasarkan Durasi Fermentasi
}

\author{
Efri Gresinta ${ }^{1}$, Rosa Dewi Pratiwi², Fitri Damayanti ${ }^{3}$, Erik Perdana Putra ${ }^{4}$ \\ 1,2,3 Universitas Indraprasta PGRI, Jakarta, Indonesia \\ 4 Tadris IPA, Institut Agama Islam Negeri Bengkulu, Indonesia \\ Coressponding Author. E-mail: \\ ${ }^{1}$ gresintaefri@gmail.com \\ 2tewe_chemist@yahoo.co.id \\ 3fitridamayantineng@gmail.com \\ 4erik.perdana@iainbengkulu.ac.id
}

Received: 5 Juli 2019

Accepted: 28 Juli 2019

Online Published: 30 Juli 2019

\begin{abstract}
Abstrak
Nata adalah bahan menyerupai gel yang terapung pada medium yang mengandung gula dan asam hasil bentukan mikroorganisme Acetobacter xylinum. Secara mikroskopik berupa massa fibril tidak beraturan yang menyerupai benang. Supaya hasil Nata berkualitas, media disesuaikan dengan syarat tumbuh (sifat fisik-kimia media) bakterinya A.xylinum. Nata de coco tanpa ZA dengan lama fermentasi 10 hari menghasilkan yield paling baik dengan ketebalan $1,1 \mathrm{~cm}$ dan berat 600 gram. Sedangkan pada nata de tomato dengan ZA memberikan yield terbaik dengan ketebalan $0,5 \mathrm{~cm}$ pada lama fermentasi 10 hari. Hal ini menunjukkan bahwa ketebalan nata de coco dengan nata de tomato berbeda. Dipengaruhi oleh variasi substrat dan komposisi bahan. Pada nata de tomato, ekstrak nata tomato dicampurkan dengan air dengan perbandingan 1:4. Hal inilah yang menyebabkan yield nata de tomato dan coco berbeda. Kandungan nutrient atau glukosa pada sari buah tomat lebih sedikit dibandingkan dengan kandungan glukosa pada nata de coco. Hasil uji organoleptik menyimpulkan bahwa : 1) Panelis lebih menyukai nata dengan tekstur kenyal yang diperoleh dari nata de coco pada hari ke-10,2) Panelis lebih menyukai nata de coco maupun tomato dengan aroma tidak asam karena pada saat dipanen, nata dicuci lalu direbus selama 20 menit pada suhu $100^{\circ} \mathrm{C}$ sehingga aroma asam pada nata hilang pada saat pencucian dan perebusan.3) Panelis lebih menyukai nata dengan rasa enak karena perbedaan lama fermentasi menghasilkan citarasa nata enak yang relatif sama.
\end{abstract}

Kata Kunci: Nata De Tomato; Nata De Coco; Durasi Fermentasi.

\begin{abstract}
Nata is a gel-like material that floats on a medium containing sugar and acid formed by the microorganism Acetobacter xylinum. Microscopically an irregular mass of fibrils that resemble threads. In order for the quality Nata results, the media are adjusted to the growth requirements (physical-chemical properties of the media) of the bacteria A.xylinum. Nata de coco without $\mathrm{Z} A$ with 10 days fermentation time produces the best yield with a thickness of $1.1 \mathrm{~cm}$ and a weight of 600 grams. Whereas the nata de tomato with $\mathrm{Z} A$ gives the best yield with a thickness of $0.5 \mathrm{~cm}$ at 10 days fermentation time. This shows that the thickness of nata de coco with nata de tomato is different. Influenced by variations in substrate and material composition. In nata de tomato, nata tomato extract is mixed with water in a ratio of 1: 4. This is what causes the yield of nata de tomato and coco to be different. Nutrient or glucose content in tomato juice is less than the glucose content in nata de coco. Organoleptic test results concluded that: 1) Panelists preferred nata with a chewy texture obtained from nata de coco on the 10th day, 2) Panelists preferred nata de coco or tomato with a non-sour aroma because when harvested, nata was washed and then boiled for 20 minutes at $100^{\circ} \mathrm{C}$ so that the acid aroma of the nata disappears during washing and boiling.3) Panelists prefer nata with good taste because the difference in fermentation time produces relatively similar delicious nata flavors..
\end{abstract}

Keywords : Nata De Coco; Nata De Tomato; Fermentation Duration

How to cite this article :

Gresinta, E., Pratiwi, R., Damayanti, F., \& Putra, E. (2019). Komparasi Yield Nata De Tomato Dengan Nata De Coco Berdasarkan Durasi Fermentasi. IJIS Edu: Indonesian Journal of Integrated Science Education, 1(2), 169-174. doi:http://dx.doi.org/10.29300/ijisedu.v1i2.2248 


\section{PENDAHULUAN}

Indonesia merupakan salah satu negaIndonesia adalah negara yang memiliki kekayaan alam yang besar. Kemajuan teknologi bidang pengolahan pangan, dapat memberikan dampak terhadap meningkatnya limbah industri pangan. Beberapa upaya telah dilakukan untuk memanfaatkan limbah dari suatu industri pertanian menjadi suatu produk yang bernilai ekonomi. Salah satu produk tersebut adalah nata.

Nata adalah bahan menyerupai gel (agaragar) yang terapung pada medium yang mengandung gula dan asam hasil bentukan mikroorganisme Acetobacter xylinum. Nata pada dasarnya merupakan selulosa. Apabila dilihat dibawah mikroskop akan tampak sebagai suatu massa fibril tidak beraturan yang menyerupai benang atau kapas (Indah, 2013). Proses pembuatan nata memerlukan bantuan bakteri Acetobacter xylinum untuk mensintesis kandungan gula dalam media menjadi selulosa. Untuk memperoleh hasil yang baik, media harus disesuaikan dengan syarat tumbuh bakteri tersebut. Untuk menghasilkan nata dengan produksi dan kualitas yang tinggi, sifat fisikokima media harus sesuai dengan syarat tumbuh dari bakteri A.xylinum.

Kandungan serat yang tinggi pada nata memberikan keuntungana pada manusia yang mengkonsumsinya. Keuntungan tersebut berupa kemampuan serat nata dalam menjaga kesehatan dan mencegah serta meminimalkan terjadinya beberapa penyakit, yaitu sebagai penurun kolesterol, glukosa darah pada penderita diabetes mellitus, mencegah konstipasi, mengendalikan berat badan (mencegah obesitas), mencegah kanker kolekteral, dan bermanfaat pada mikroflora di usus besar.

Nata dapat dibuat dari berbagai macam bahan dasar, seperti sari buah-buahan dan sayuran. Salah satu contoh produk nata yang terkenal di pasaran adalah nata de coco. Nata de coco adalah nata yang dibuat dari sari buah kelapa. Selain nata de coco masih ada contoh-contoh produk nata lainnya misalnya nata de soya, nata de pina, nata de cassava, nata de lerry, dan lain-lain. Devi (2007) juga menyebutkan adapun bahan-bahan alternatif yang ditemukan dalam pembuatan produk pangan berupa nata, yaitu nata yang terbuat dari berbagai buah-buahan seperti nenas (nata de pina), tomat (nata de tomato), dan buah-buahan lain yang cukup banyak mengandung gula. Disebutkan diatas terdapat satu lagi contoh produk nata yang dibuat dari bahan dasar sari tomat. Nata ini disebut nata de tomato. Meskipun bahan dasar nata ini mudah diperoleh, namun produksinya masih terbatas di daerah tertentu seperti Bali. Untuk daerah Jakarta, penulis belum pernah menemukan produk nata de tomato.

Nata de tomato memiliki kandungan gizi yang tidak kalah dari produk-produk nata lainnya, terutama nata de coco. Tomat sebagai bahan dasar nata de tomato memiliki berbagai macam kandungan gizi. Buah tomat kaya akan vitamin A, C, K, folat dan kalium. Kandungan vitamin A baik untuk kesehatan mata, selain itu tomat juga mengandung Lycopen yang terbukti efektif sebagai zat anti oksidan. Oleh karena itu, tomat baik untuk menurunkan resiko terkena kanker.

Buah tomat sendiri adalah buah yang mudah ditemui, harganya yang relatif murah namun tidak tahan lama (mudah busuk), sehingga perlu alternatif dalam pemanfaatannya, yaitu melalui proses fermentasi. Dalam fermentasi ini semua jenis tomat dapat dimanfaatkan sebagai bahan baku pembuatan nata de tomato. Proses pembuatannya pun tidak jauh berbeda dengan nata de coco. Hal-hal di atas adalah beberapa keunggulan dari nata de tomato. Dari uraian diatas, penulis membatasi penelitian yaitu bagaimana perbedaan yield nata de coco dengan nata de tomato berdasarkan variasi waktu fermentasi dan kadar ZA.

\section{METODE PENELITIAN}

Peralatan dalam pembuatan nata meliputi baki fermentasi, kertas lakmusuntuk mengukur $\mathrm{pH}$, timbangan, pisau, gelas ukur, blender, panci, kompor, pengaduk, saringan, kertas koran, karet gelang. Alat untuk analisa kadar serat adalah neraca analitik, gelas ukur, pengaduk, pipet volum, erlenmeyer, pendingin balik, kertas saring, kertas lakmus, spatula, desikator, kurs porselin. Alat untuk uji organoleptik terdiri dari formulir uji organoleptik, bolpoin, piring kecil, dan gelas. Alat untuk menguji mutu fisik yaitu warna adalah chromameter, alat menghitung rendemen adalah timbangan sedangkan mengukur ketebalan menggunakan jangka sorong. Sedangkan bahan yang digunakan adalah sari buah tomat, air kelapa, gula pasir, asam cuka 25\%, starter Acetobacter Xyllinum, dan ZA food grade.

Langkah pembuatan nata sebagai berikut: 1) Mensterilakn seluruh alat yang akan digunakan menggunakan air panas, 2) Menakar 1 liter air kelapa/ sari buah tomat meggunakan alat takar, 3) Menuangkan 1 liter air kelapa/ sari buah tomat kedalam panic, 4) Memanaskan 1 liter air kelapa/ sari buah tomat diatas kompor, 5) Mengaduk sampai mendidih dan menambahkan ZA food grade sebanyak $1 / 2 \mathrm{sdt}$, gula pasir $2 \mathrm{sdm}$, asam cuka $10 \mathrm{~mL}$, 6) Menuangkan bahan nata ke dalam bak fermentasi, 7) Menutup dengan segera bak 
fermentasi menggunakan Koran, 8) Menyimpannya dan menunggu bahan nata sampai dingin, 9) Menambahkan acetobakter xylinum ke dalam bahan nata sebanyak $100 \mathrm{~mL}, 10)$ Melakukan langkah 1-9 untuk setiap 1 bak fermentasi dengan beberapa perlakuan yang berbeda, 11) Memanen nata setelah mengalami fermentasi selama 7 hari dan 10 hari, 12) Membersihkan bagian atas nata, 13) Memotong nata sesuai ukuran tertentu, dan 14) Merebus nata selama 15 menit dan nata siap disajikan dengan sirup ataupun air gula.

Dalam penelitian ini dilakukan uji fisik dan organoleptik. Untuk mengetahui sifat organoleptik masing-masing yield nata maka penulis menyajikan kuesioner kepada 34 responden.

\section{HASIL DAN PEMBAHASAN}

Nata adalah bahan menyerupai gel (agaragar) yang terapung pada medium yang mengandung gula dan asam hasil bentukan mikroorganisme Acetobacter xylinum. Nata pada dasarnya merupakan selulosa. Apabila dilihat dibawah mikroskop akan tampak sebagai suatu massa fibril tidak beraturan yang menyerupai benang atau kapas (Nainggolan, 2009). Proses pembuatan nata memerlukan bantuan bakteri Acetobacter xylinum untuk mensintesis kandungan gula dalam media menjadi selulosa. Untuk memperoleh hasil yang baik, media harus disesuaikan dengan syarat tumbuh bakteri tersebut. Salah satu faktor yang mempengaruhi jumlah serat dalam nata yaitu jumlah kandunagn nitrogen dalam bahan. Hal yang sama juga dikatakan dalam penelitian yang dilakukan Niarda Arifiani (2015), bahwa semakin tinggi konsentrasi nitrogen yang digunakan maka, kandungan serat juga akan semakin meningkat. Oleh karena itu Untuk menghasilkan nata dengan produksi dan kualitas yang tinggi, sifat fisik-kimia media harus sesuai dengan syarat tumbuh dari bakteri A.xylinum.

\section{Mutu Fisik Nata}

Hasil penelitian ini menunjukkan bahwa yield nata de tomato dan nata de coco memiliki perbedaan berdasarkan variasi lama fermentasi dan kadar ZA.

Tabel 1. Hasil Uji Fisik Nata

\begin{tabular}{lcccc}
\hline Jenis Nata & \multicolumn{2}{c}{ Ketebalan $(\mathrm{cm})$} & \multicolumn{2}{c}{ Berat (gram) } \\
\cline { 2 - 5 } & \multicolumn{2}{c}{ Lama Fermentasi (hari) } & \multicolumn{2}{c}{ Lama Fermentasi (hari) } \\
\cline { 2 - 5 } & 7 & 10 & 7 & 10 \\
\hline Coco ZA & 0,7 & 0,5 & 400 & 300 \\
\hline Coco Non ZA & 0,8 & 1,1 & 500 & 600 \\
\hline Tomato ZA & 0,2 & 0,5 & 200 & 300 \\
\hline $\begin{array}{l}\text { Tomato Non } \\
\text { ZA }\end{array}$ & 0,1 & 0,3 & 100 & 200 \\
\hline
\end{tabular}

Dari tabel diatas, dapat kita simpulkan bahwa semakin lama fermentasi maka yield nata yang dihasilkan semakin tebal dan berat. Hal ini dikarenakan aktivitas bakteri Acetobacter xylinum dalam menghasilkan selulosa dipengaruhi lama fermentasi dan perbedaan nilai serat yang terkandung pada masing-masing bahan. Serat kasar yang dihasilkan tersebut merupakan hasil perombakan gula pada medium fermentasi oleh aktivitas bakteri Acetobacter xylinum (Anastasia dan Eddy 2008).

Dari data tersebut juga memperlihatkan perbedaan ketebalan serat yang dihasilkan pada masing-masing bahan. Perbedaan serat pada kedua bahan disebabkan adanya perbedaan kadar nutrien yang tersedia dalam medium. Nilawati et al. (1997) menyatakan bahwa kandungan nutrisi yang tersedia dalam medium seperti karbohidrat, protein, lemak abu dan vitamin B-kompleks lainnya mempengaruhi pembentukan selulosa oleh Acetobacter xylinum. Nutrien adalah substansi anorganik dan organik yang dalam larutan melintasi membran sitoplasma. Agar mendapatkan nutrien dari makanan, sel harus mampu mencerna makanan tersebut dengan cara mengubah molekul-molekul protein, karbohidrat, dan lipida yang kompleks dan besar menjadi molekul yang sederhana dan kecil dan segera melarut sehingga dapat memasuki sel. (Pelczar \& Chan, 1989).

\section{Uji Organoleptik}

Uji organoleptik dilakukan dengan menggunakan uji skoring henodik dengan kriteria semakin tinggi angka maka mutunya semakin baik. Aspek yang dinilai meliputi tingkat kesukaan terhadap tekstur, warna, rasa dan aroma, dimana panelis dimintai tanggapan pribadinya tentang kesukaan atas suatu produk menurut tingkatan- 
tingkatan tertentu. Panelis yang digunakan adalah sebanyak 33 orang dari mahasiswa pendidikan Biologi Universitas Indraprasta PGRI.

Tabel 2. Penilaian Responden Terhadap Uji Sensoris

\begin{tabular}{llllll}
\hline \multirow{2}{*}{ Jenis Nata } & \multicolumn{5}{c}{ Uji Sensoris } \\
& Warna $(\mathrm{W})$ & Aroma $(\mathrm{A})$ & Rasa $(\mathrm{R})$ & Tekstur $(\mathrm{T})$ & rerata \\
\hline A1 & 73 & 48 & 56 & 70 & 61.75 \\
A2 & 74 & 55 & 56 & 70 & 63.75 \\
A3 & 78 & 63 & 62 & 73 & 69 \\
A4 & $\mathbf{8 6}$ & $\mathbf{8 2}$ & $\mathbf{9 0}$ & $\mathbf{8 7}$ & $\mathbf{8 6 . 2 5}$ \\
B1 & 76 & 61 & 63 & 73 & 68.25 \\
B2 & 70 & 61 & 67 & 67 & 66.25 \\
B3 & $\mathbf{7 1}$ & $\mathbf{7 0}$ & $\mathbf{6 8}$ & $\mathbf{7 1}$ & $\mathbf{7 0}$ \\
B4 & 72 & 71 & 66 & 70 & 69.75 \\
\hline
\end{tabular}

\section{PEMBAHASAN}

Penelitian ini menunjukkan bahwa bakteri Acetobacter xylinum bekerja membentuk lapisan natayang semakin tebal sampai pada hari ke-10 dan bakteri Acetobacter xylinum masih mampu beraktivitas untuk tumbuh dan membentuk selulosa. Putriana (2013) menyatakan bahwa nata yang dipanen setelah hari ke-13 tidak akan terbentuk lapisan nata baru karena aktivitas bakteri Acetobacter xylinum berhenti akibat nutrisi yang habis di dalam media fermentasi dan hasil metabolit berupa asam asetat yang dapat mengganggu pertumbuhan mikroba. Saccharomyces menguraikan gula menjadi etanol lalu oleh Accetobacter xylinum diubah menjadi asam asetat, sehingga $\mathrm{pH}$ medium menjadi lebih asam yaitu 3 dan aroma juga menjadi asam. Beberapa hasil penelitian melaporkan bahwa ada beberapa faktor yang mempengaruhi pertumbuhan A. Xylinum antara lain sumber karbon, nitrogen, tingkat keasaman $(\mathrm{pH} 3-4)$, temperatur optimal $\left(28^{\circ} \mathrm{C}-31^{\circ} \mathrm{C}\right)$ dan oksigen.

Nutrien yang dibutuhkan oleh bakteri selama proses kehidupannya adalah makanan yang mengandung unsur $\mathrm{C}, \mathrm{H}, \mathrm{O}$ dan $\mathrm{N}$ yang berguna untuk menyusun protoplasma. Nutrien yang berperan utama dalam proses fermentasi oleh Acetobacter xylinum adalah karbohidrat sebagai sumber energi dan untuk perbanyakan sel (Kadir, 2003). Ani, dkk (2012) menambahkan bahwa bakteri Acetobacter xylinum dalam membentuk nata di dalam media yang diperkaya karbon dan nitrogen, penambahan asam asetat, sehingga menstimulasi khamir S.Cerreviceae untuk merombak sukrosa menjadi glukosa dan kemudian difermentasi menjadi alkohol, selanjutnya Accetobacter xylinum dan Gluconobacter mengoksidasi alkohol menjadi asam asetat sebagai metabolit utama. Diperkuat oleh penelitian Jagannath, dkk (2008) menunjukkan bahwa $A$. xylinum dapat secara efektif menggunakan sukrosa sebagai satu-satunya sumber karbon dalam media air kelapa dan bahwa produksi selulosa lebih tergantung pada $\mathrm{pH}$ daripada konsentrasi sukrosa atau amonium sulfat. Ketebalan nata maksimum diperoleh pada $\mathrm{pH} 4.0$ dengan sukrosa $10 \%$ dan konsentrasi amonium sulfat $0,5 \%$. Kondisi ini juga menghasilkan nata-decoco berkualitas baik dengan permukaan halus dan tekstur kenyal yang lembut.

Bakteri Accetobacter xylinum menghasilkan enzim ekstraseluler yang dapat menyusun (mempolimerisasi) zat gula (glukosa) menjadi ribuan rantai (homopolimer) serat atau selulosa. Dari jutaan jasad renik yang tumbuh dalam media, akan dihasilkan jutaan lembar benang-benang selulosa yang akhirnya nampak padat berwarna putih hingga transparan, yang disebut sebagai nata yang termasuk metabolit sekunder. Pada fermentasi nata terjadi hubungan saling membutuhkan antara khamir S.Cerreviceae, Gluconobacer, dan Accetobacte rxylinum. Saccharomyces menguraikan gula menjadi etanol lalu oleh Accetobacter xylinum dan Gluconobacter di oksidasi menjadi asam asetat dan air. Accetobacter xylinum memerlukan waktu untuk fase adaptasi selama 1 hari, kemudian pertumbuhan meningkat (faselogaritmik) sampai pada hari ke-5 dan ke-7 ditunjukkan dengan semakin tebal nata yang terbentuk.

Nata de coco tanpa ZA dengan lama fermentasi 10 hari memberikan yield paling baik dengan ketebalan $1,1 \mathrm{~cm}$ dan berat 600 gram. Sedangkan pada nata de tomato dengan ZA memberikan yiels terbaik dengan ketebalan $0,5 \mathrm{~cm}$ pada lama fermentasi 10 hari. Hal inimenunjukkan bahwa ketebalan nata de coco dengan nata de tomato 
berbeda. Hal ini dipengaruhi oleh variasi substrat dan komposisi bahan. Pada nata de tomato, ekstrak nata tomato dicampurkan dengan air dengan perbandingan 1:4. Kemungkinan hal inilah yang menyebabkan yield nata de tomato dan coco berbeda. Hal tersebut dipengaruhi jumlah nitrogen yang terdapat dalam medium atau bahan yang digunakan. Kandungan nutrient atau glukosa pada sari buah tomat lebih sedikit dibandingkan dengan kandungan glukosa pada nata de coco. Tekstur yang baik untuk nata adalah kenyal dan tidak keras. Menurut Souisa (2006), kadar serat kasar akan berbanding lurus dengan kekenyalan atau tekstur.
Sehingga perlakuan konsentrasi nitrogen yang tertinggi akan memiliki tekstur nata yang kenyal.

Rasa yang baik untuk nata de cassava adalah enak dengan ditambahkan larutan gula 10\%. Aroma yang baik untuk nata adalah tidak asam. Berdasarkan penilaian panelis atau responden, jenis nata yang paling disukai adalah nata de coco tanpa pemberian ZA food grade (A4) dengan lama fermentasi 10 hari.

Jenis nata de coco ternyata lebih disukai dibandingkan nata de tomato. Dari kelompok nata de tomato, B3 paling disukai yaitu nata de tomato dengan lama fermentasi 10 hari dan dengan pemberian ZA food grade.

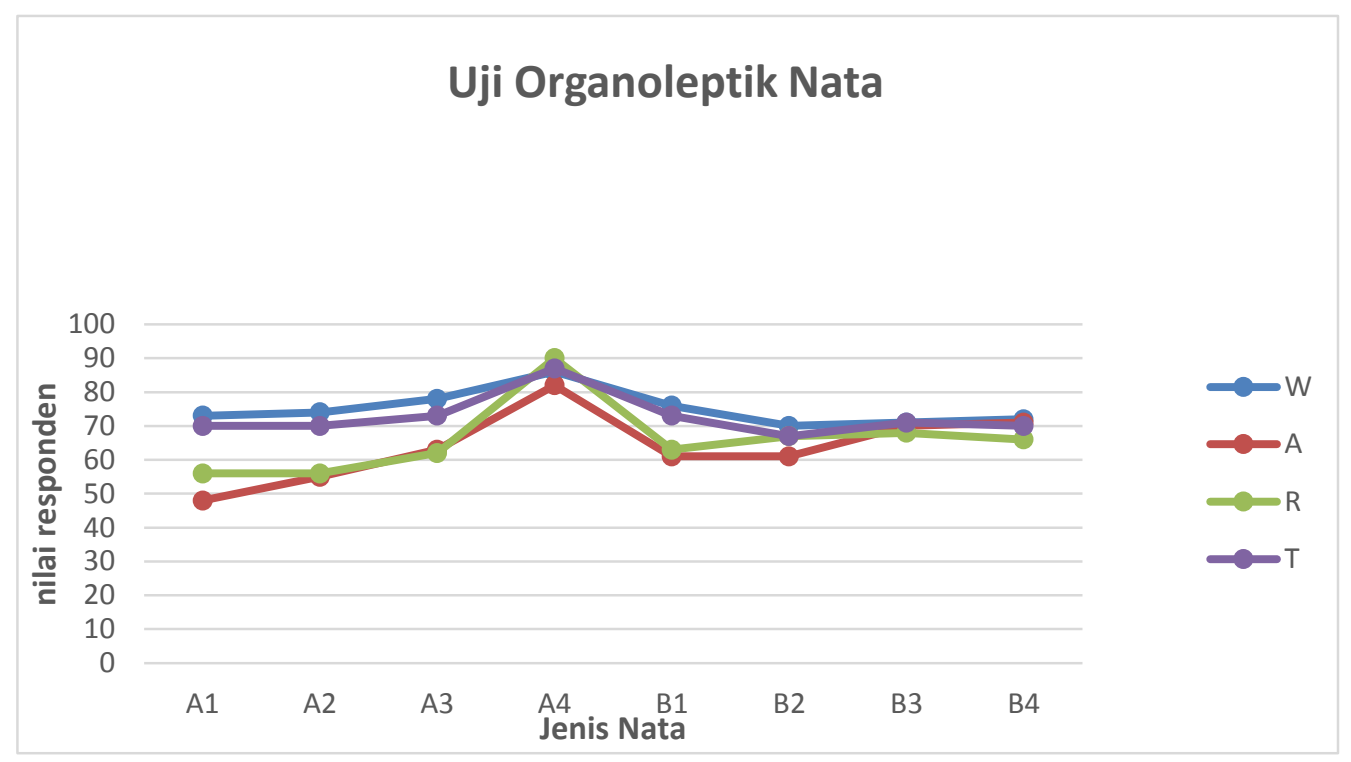

Gambar 1. Chart Representasi Panelis Terhadap Nata

Dapat disimpulkan bahwa : 1) Panelis lebih menyukai nata dengan tekstur kenyal yang diperoleh dari nata de coco pada hari ke-10, hal ini disebabkan selulosa yang terbentuk oleh bakteri Acetobacter xylinum belum terlalu keras sehingga tekstur menjadi kenyal. Semakin lama fermentasi tekstur nata semakin lembek karena lapisan nata yang terbentuk semakin tebal. 2) Panelis lebih menyukai nata de coco maupun tomato dengan aroma tidak asamkarena pada saat dipanen, nata dicuci lalu direbus selama 20 menit pada suhu $100^{\circ} \mathrm{C}$ sehingga aroma asam pada natahilang pada saat pencucian danperebusan.3) Panelis lebih menyukai natadengan rasa enak karena perbedaan lama fermentasi menghasilkan citarasa nata enak yang relatif sama, selain itu pada saat pengujian organoleptik nata disajikan menggunakan larutan gula sebesar $10 \%$, sehingga nata berasa manis dan enak.

\section{KESIMPULAN}

Berdasarkan penelitian yang dilakukan dapat disimpulkan bahwa tomat dapat digunakan sebgai bahan baku pembuatan nata. Produksi nata tomat terbaik pada lama fermentasi 10 hari dengan penambahan ZA food grade, dengan berat 300 gram dan ketebalan $0,5 \mathrm{~cm}$. Sedangkan untuk nata de coco terbaik pada perlakuan tanpa pemberian ZA food grade dengan lama fermentasi 10 hari, dengan berat 600 gram dan ketebalan 1,1 cm. Penilaian panelis terhadap kedua nata adalah panelis lebih menyukai nata de coco karena bertekstur kenyal, aroma sedap (tidak asam), rasanya enak dan warnanya putih bersih. 


\section{DAFTAR PUSTAKA}

Ani, dkk. 2012. Membuat Aneka Nata. Jakarta: Naga Swadaya.

Anastasia. N, Eddy A., 2008. Mutu Nata de Seaweed dalam Berbagai Konsentrasi Sari Jeruk Nipis. Prosiding. Program Studi Perikanan. Fakultas Perikanan dan Ilmu Kelautan Universitas Padjadjaran. Bandung.

Devi, R. 2007. Kajian Variasi Kadar Glukosa dan Derajat Keasaman ( $p H)$ Pada Pembuatan Nata de Citrus Dari Jeruk Asam (Citrus limon. L). Jurnal Gradien Vol. 3 (2): 257.

Indah, P. 2013. Mutu Fisik, Kadar Serat, dan Sifat Organoleptik. Nata de Cassava Berdasarkan Lama Fermentasi. Jurnal Pangan dan Gizi Vol 4 No. 07 Th. 2013. Universitas Muhammadiyah Semarang.

Jagannath, A. et al. 2008. The effect of $p H$, sucrose and ammonium sulphate concentrations on the production of bacterial cellulose (Nata-de-coco) by Acetobacter xylinum. World Journal of Microbiology and Biotechnology, 24:2593.

Kadir, S. 2003. Karakteristik Nata de Coco Dari Starter Ampas Nenas Melalui Penambahan Sukrosa Dan Keasaman Medium. Journal Agroland 10(2):145-150.

Nainggolan, J. 2009. Kajian Pertumbuban Bakteri Accetobacter sp. Dalam Kombucha-Rosela Merah (Hibiscus sabdariffa) pada Kadar Gula dan Lama Fermentasi yang Berbeda. (Tesis). Medan: Universitas Sumatera Utara.

Niarda, A., Sani, T.A. Utami, A.S. 2015. Peningkatan Kualitas Nata de Cane dari Limbah Nira Tebu Metode Budchips dengan Penambahan Ekstrak Tange Sebagai Sumber Nitrogen. Jurnal Bioteknologi vol.12 (2): 29-33.

Nilawati; K. Hariyanto; L. Halimah. 1997. Pengaruh Lama Penyimpanan Limbah Cair Tahu Dan Konsentrasi Asam Asetat Terhadap Mutu Nata De Soya. Buletin HPI Balai Industri Banda Aceh. Vol. X: 01-02.

Pelczar, M. J., Chan, ECS. 1989. Dasar-dasar Mikrobioogi. Jilid 1. Terjemahan. UI Press, Jakarta.

Priyantini., W., 2013. Evaluasi Sifat Fisik Nata dengan Ekstrak Kecambah Sebagai
Pengganti Sumber Nitrogen. Universitas Negeri Semarang. ISBN: 978-602-61599-6-0

Souisa, M.G., Sidharta, \& F. Sinung. 2006. Pengaruh Acetobacter xylinum dan Ekstrak. Kacang Hijau (Phaseolus radiatus) Terbadap Produksi Nata dari Substrat Limbah Cair Tabu. Biota Fakultas Biologi, Universitas Atmajaya, Yogyakarta.

Susanti, L. 2006. Perbedaan Penggunaan Jenis Kulit Pisang Terbadap Kualitas Nata. (Skripsi). Semarang. Universitas Negeri Semarang. 